\title{
Fatty acids and expression of lipid-related genes in adipose cells
}

\author{
BY GÉRARD AILHAUD, EZ-ZOUBIR AMRI AND \\ PAUL-ANDRÉ GRIMALDI* \\ Centre de Biochimie (UMR 134 CNRS), Université de Nice-Sophia Antipolis, Faculté des Sciences, \\ Parc Valrose, 06108 Nice cédex 2, France
}

\section{Acides gras et régulation de l'expression des gènes du metabolisme des lipides dans la cellule adipeuse}

\section{RÉSUMÉ}

Les acides gras sont connus à la fois comme nutriments énergétiques, comme composants des membranes biologiques et comme précurseurs de prostaglandines. Des observations récentes ont montré que, dans les préadipocytes, les acides gras à longue chaîne soit naturels et métabolisables soit non-métabolisables régulent à un niveau transcriptionnel l'expression de plusieurs gènes codant pour des enzymes et des protéines du métabolisme des lipides. Il s'agit des gènes codant pour l'adipocyte lipid-binding protein (ALBP ou aP2 ou A-FABP), l'acyl-CoA synthétase à large spécificité de substrat (ACS) et le transporteur des acides gras (fatty acid transporter; FAT). L'utilisation d'acides gras non métabolisables a permis de montrer que la concentration intracellulaire en acides gras (libre + lié) était égale à la concentration externe en acides gras libres (non associés à l'albumine). Bien que les acides gras intracellulaires devraient se trouver à l'état libre à de très faibles concentrations, ils sont cependant susceptibles de réguler l'expression génique. Les acides gras, tout comme l'acide rétinoïque qui se trouve être un acide gras non activé en acyl-CoA, se comportent au niveau nucleáire comme des hormones et stimulent la transcription par l'intermédiaire de récepteurs nucléaires. Un tel récepteur a été cloné et séquencé chez la souris. Il est homologue du facteur trans-actif humain NUC-I de la famille des peroxisome proliferator-activated receptors (PPAR) et confère à la cellule la capacité de répondre aux acides gras par activation génique. Plus encore, une exposition brève des préadipocytes aux acides gras est suffisante pour les faire entrer en différenciation terminale et stimuler la formation d'adipocytes in vitro à partir de préadipocytes.

L'ensemble de ces observations suggère que, in vivo, une augmentation post-prandiale trop considérable du flux d'acides gras entrant dans le tissu adipeux devrait accroître la probabilité que des concentrations seuils soient atteintes et de ce fait conduisent, en présence des autres hormones adipogéniques, à une hyperplasie du tissu adipeux, phénomène observé chez les rongeurs nourris avec des régimes riches en lipides ou en glucides.

Since the identification of long-chain fatty acids (FA) as essential components of cellular lipids, FA have been characterized as essential membrane components and as precursors

* For reprints. 
of prostaglandins. More recently, FA have been shown to modulate ion-channel activation, enzyme function and synaptic transmission (for review, see Orday et al. 1991). The present review does not attempt to summarize the many biological effects of FA; it only addresses one area of FA research where significant new insights have been gained over the last few years. This area relates to the role of intracellular FA as transcriptional regulators. The central aim of the present report is to highlight the importance of FA supply to the cell in regulating expression of lipid-related genes in adipose cells as this might help to understand FA involvement in the pathophysiology of multiple conditions.

\section{FATTY ACIDS AS TRANSCRIPTIONAL REGULATORS}

The process of adipose cell differentiation is sequential and takes place as follows:

adipoblasts $\stackrel{\text { commitment }}{\longrightarrow}$ pre-adipose cells $\stackrel{\text { terminal differentiation }}{\longrightarrow}$ adipose cells

(for review, see Ailhaud et al. 1992). The first evidence of a role for FA as transcriptional regulators was obtained in cultured Ob1771 pre-adipose cells (Amri et al. 1991) which rely exclusively on exogenous sources for FA supply (Ailhaud et al. 1992) with respect to the expression of the adipocyte lipid-binding protein (ALBP or aP2 or A-FABP) gene. FA effects were reversible on removal and required on-going protein synthesis. Run-on assays showed that the regulation was primarily transcriptional. $\alpha$-Bromopalmitate was much more potent than native FA in inducing the expression of ALBP and acyl-CoA synthetase (ACS) genes (Grimaldi et al. 1992; Ailhaud et al. 1994). It is of interest to note that lipoprotein lipase (EC 3.1.1.34; LPL) gene was expressed on a constitutive basis in pre-adipose cells, i.e. synthesis and secretion of LPL able to hydrolyse exogenous triacylglycerol-rich lipoprotein particles were taking place in the absence of any FA supplementation. Altogether, these results indicate that FA metabolism is not required to activate the expression of lipid-related genes in pre-adipose cells and subsequently to modulate this expression once the cells have become differentiated.

\section{LONG-TERM EFFECTS OF FATTY ACIDS ON ADIPOSE CELL DIFFERENTIATION}

Chronic exposure of Ob1171 cells to FA led to a strong, dose-dependent stimulation of cell differentiation. This effect was confined to terminal events, whereas FA did not affect expression of early genes related to commitment of adipoblasts to pre-adipose cells. Adipogenic action of FA did not require their metabolism since $\alpha$-bromopalmitate, which is not metabolized by pre-adipose cells, was more effective than palmitate in inducing differentiation (Amri et al. 1994). Taken together these observations suggest that at the pre-adipose state an increase in the intracellular concentration of unprocessed FA plays the role of a signal triggering the expression of terminal differentiation-related genes. At that stage, pre-adipose cells did not yet express ALBP but did express a newly discovered fatty acid-binding protein (FABP; MalI or epidermal FABP; Krieg et al. 1993). Thus, it is likely that minute concentrations of unbound FA which are present within the cell are sufficient to activate the expression of lipid-related genes. 


\section{TRANS-ACTING FACTORS AND FATTY ACID RESPONSIVENESS}

The FA effects are reminiscent of those exerted by retinoids and fibrates, which are also amphipathic carboxylates, on adipose cell differentiation (Verrando et al. 1981) and on the expression of genes encoding enzymes involved in lipid metabolism of hepatocytes (Green, 1992). It has been demonstrated that the transcriptional effects of fibrates are mediated by means of activation of the nuclear hormone receptor superfamily, i.e. peroxisome proliferator-activated receptor (PPAR) isolated from a mouse liver cDNA library (Issemann \& Green, 1990). Subsequently, three PPAR receptors $(\alpha, \beta$, and $\gamma$ ) have been described in Xenopus laevis (Dreyer et al. 1992), three other forms in mouse (Chen et al. 1993; Zhu et al. 1993; Kliewer et al. 1994), two in human subjects (Schmidt et al. 1992; Sher et al. 1993) and another one in rat (Gottlicher et al. 1992). We have recently identified a member of the nuclear hormone receptor superfamily by cDNA cloning from a mouse pre-adipose Ob1771 cell library. The cDNA has the characteristics and ligand-binding domains of nuclear hormone receptors and encodes a 440 amino acid protein related to PPAR. The deduced protein sequence is $88 \%$ homologous to that of hNUC-I, isolated from human osteosarcoma cells. The fatty acid-activated receptor (FAAR) mRNA is abundant in adipose tissue, intestine, brain, heart and skeletal muscles, and less abundant in kidney, liver, testis, and spleen. The mRNA is undetectable in growing Ob1771 and 3T3-F442A pre-adipocytes, is strongly induced early during differentiation, and is increased by FA. Transcription assays using hybrid receptor have shown strong stimulation by FA and weaker induction by fibrates. Transfection of 3T3-C2 fibroblasts, with a FAAR expression vector, confers FA inducibility of the ALBP and fatty acid transporter (FAT). Transcriptional induction of these genes exhibits inducer specificity identical to that described in pre-adipocytes. Stable transfectants expressing FAAR constitutively are also able to differentiate into adipose cells only in the presence of FA (P. Grimaldi, E. Amri, D. Gaillard and L. Teboul, unpublished results). Such a new role for $\mathrm{FA}$ as transducing molecules remains to be assessed in vivo, but it can be assumed that after a high-fat or a high-carbohydrate diet the flux of FA entering pre-adipose cells from chylomicrons and VLDL respectively should be significantly increased. If it were so, this would explain why hypertrophy and hyperplasia of adipose tissue are triggered, thus providing a link between adipogenic diets and the excessive development of adipose tissue (Faust et al. 1978; Klyde \& Hirsch, 1979).

The authors thank F. Bonino for technical assistance and Mrs G. Oillaux for secretarial assistance.

\section{REFERENCES}

Ailhaud, G., Abumrad, N., Amri, E. Z. \& Grimaldi, P. A. (1994). A new look at fatty acids as signal transducing molecules. World Review of Nutrition and Dietetics 75, 35-45.

Ailhaud, G., Grimaldi, P. \& Négrel, R. (1992). Cellular and molecular aspects of adipose tissue development. Annual Review of Nutrition 12, 207-233.

Amri, E., Ailhaud, G. \& Grimaldi, P. A. (1994). Fatty acids as signal transducing molecules: involvement in the differentiation of preadipose to adipose cells. Journal of Lipid Research 35, 930-937.

Amri, E., Bertrand, B., Ailhaud, G. \& Grimaldi, P. (1991). Regulation of adipose cell differentiation. I. Fatty acids are inducers of aP2 gene expression. Joumal of Lipid Research 32, 1449-1456.

Chen, F., Law, S. W. \& O’Mahley, B. W. (1993). Identification of two mPPAR related receptors and evidence for the existence of five subfamily members. Biochemical and Biophysical Research Communications 196, $671-677$. 
Dreyer, C., Krey, G., Keller, H., Givel, F., Heftenbein, G. \& Wahli, W. (1992). Control of peroxisomal $\beta$-oxidation pathway by a novel family of nuclear hormone receptors. Cell 68, 879-887.

Faust, I. M., Johnson, P. R., Stern, J. S. \& Hirsch, J. (1978). Diet-induced adipocyte number increase in adult rats: a new model of obesity. American Journal of Physiology 235, E279-E286.

Gottlicher, M., Widmark, E., Li, Q. \& Gustafsson, J. A. (1992). Fatty acids activate a chimera of the clofibric acid-activated receptor and the glucocorticoid receptor. Proceedings of the National Academy of Sciences, USA 89, 4653-4657.

Green, S. (1992). Receptor-mediated mechanisms of peroxisome proliferators. Biochemical Pharmacology $\mathbf{4 3}$, 393-401.

Grimaldi, P. A., Knobel, S. M., Whitesell, R. \& Abumrad, N. (1992). Induction of the aP2 gene by nonmetabolized long chain fatty acids. Proceedings of the National Academy of Sciences, USA 89, $10930-10934$.

Issemann, I. \& Green, S. (1990). Activation of a member of the steroid hormone receptor superfamily by peroxisome proliferators. Nature 347, 645-650.

Kliewer, S. A., Forman, B. M., Blumberg, B., Ong, E. S., Borgmeyer, U., Mangelsdorf, D. J., Umesono, K. \& Evans, R. M. (1994). Differential expression and activation of a family of murine peroxisome proliferator-activated receptors. Proceedings of the National Academy of Sciences, USA 91, 7355-7359.

Klyde, J. B. \& Hirsch, J. (1979). Increased cellular proliferation in adipose tissue of adult rats fed a high-fat diet. Journal of Lipid Research 20, 705-715.

Krieg, P., Feil, S., Furstenberg, G. \& Bowben, G. T. (1993). Tumor-specific overexpression of a novel keratinocyte lipid-binding protein. Journal of Biological Chemistry 268, 17362-17369.

Ordway, R. N., Singer, J. J. \& Walsh, J. V. (1991). Regulation of ion channels by fatty acids. Trends in Neurosciences 14, 96-100.

Schmidt, A., Endo, N., Rutledge, S. J., Vogel, R., Shinar, D. \& Rodan, G. A. (1992). Identification of a new member of the steroid hormone receptor superfamily that is activated by a peroxisome proliferator and fatty acids. Molecular Endocrinology 6, 1634-1641.

Sher, T., Yi, H. F., McBride, O. W. \& Gonzales, F. J. (1993). cDNA cloning, chromosomal mapping, and functional characterization of the human peroxisome proliferator activated receptor. Biochemistry 32, 5598-5604.

Verrando, P., Négrel, R., Grimaldi, P., Murphy, M. \& Ailhaud, G. (1981). Differentiation of Ob17 preadipocytes: triggering effects of clofenapate and indomethacin. Biochimica et Biophysica Acta 663, 255-265.

Zhu, Y., Alvares, K., Huang, Q., Rao, M. S. \& Reddy, J. K. (1993). Cloning of a new member of the peroxisome proliferator-activated receptor gene family from mouse liver. Journal of Biological Chemistry 268, 26817-26820. 